\title{
EXPLORING THE EDWARD J. BLOUSTEIN DICTIONARY COLLECTION
}

\author{
BY JEFFERY A. TRIGGS \\ Jeffery Triggs is an applications developer in the Scholarly Communications \\ Center, Rutgers University Libraries, and former director of the North \\ American Reading Program for the Oxford English Dictionary.
}

It is a comparatively rare enterprise to amass a great personal collection of dictionaries. Unless they have a professional interest in lexicography, ${ }^{1}$ most people approach dictionaries in a more or less utilitarian spirit, and as often as not they tend to make do with whatever comes, conveniently or serendipitously, their way: the latest Merriam-Webster's Collegiate received as a graduation gift, a battered but still useful Funk E Wagnalls inherited from one's least favorite uncle, or perhaps even a Compact Oxford English Dictionary (with magnifying glass) picked up as a reward for joining the Book of the Month Club. And having found their dictionaries, most people fall in love with them-or at least grow used to them-and tend to hold on to them rather uncritically through the years. One dictionary is enough for most people, unlike, say, one book of poems, one novel, or even one history of the Civil War.

When I was a student at Rutgers, The State University of New Jersey, in the late seventies and early eighties, we never imagined that our president, Edward J. Bloustein, was a man with a keen and informed interest in lexicography, but he was indeed just that, and now the Rutgers University Libraries are fortunate to be in possession of his extensive personal library of dictionaries. These range from Thomas Cooper's Latin/English glossary, Thesaurus linguae Romanae et Britannicae ( I573) to the Webster's Third New International Dictionary (I96I) edited by Philip Gove, though the main periods of concentration are the eighteenth and nineteenth centuries, during which time the dictionary as a genre evolved into its recognizably modern forms. The 170 individual titles in the collection (most of them in multiple editions) offer scholars a remarkable set of rare primary resources not only for the study of English lexicography, but also for the study of the development of the English language itself in Great Britain and the United States and its

Journal of the Rutgers University Libraries, Volume LXI, pp. 28-47

Copyright 2005 by the Rutgers University Libraries. All rights reserved. 


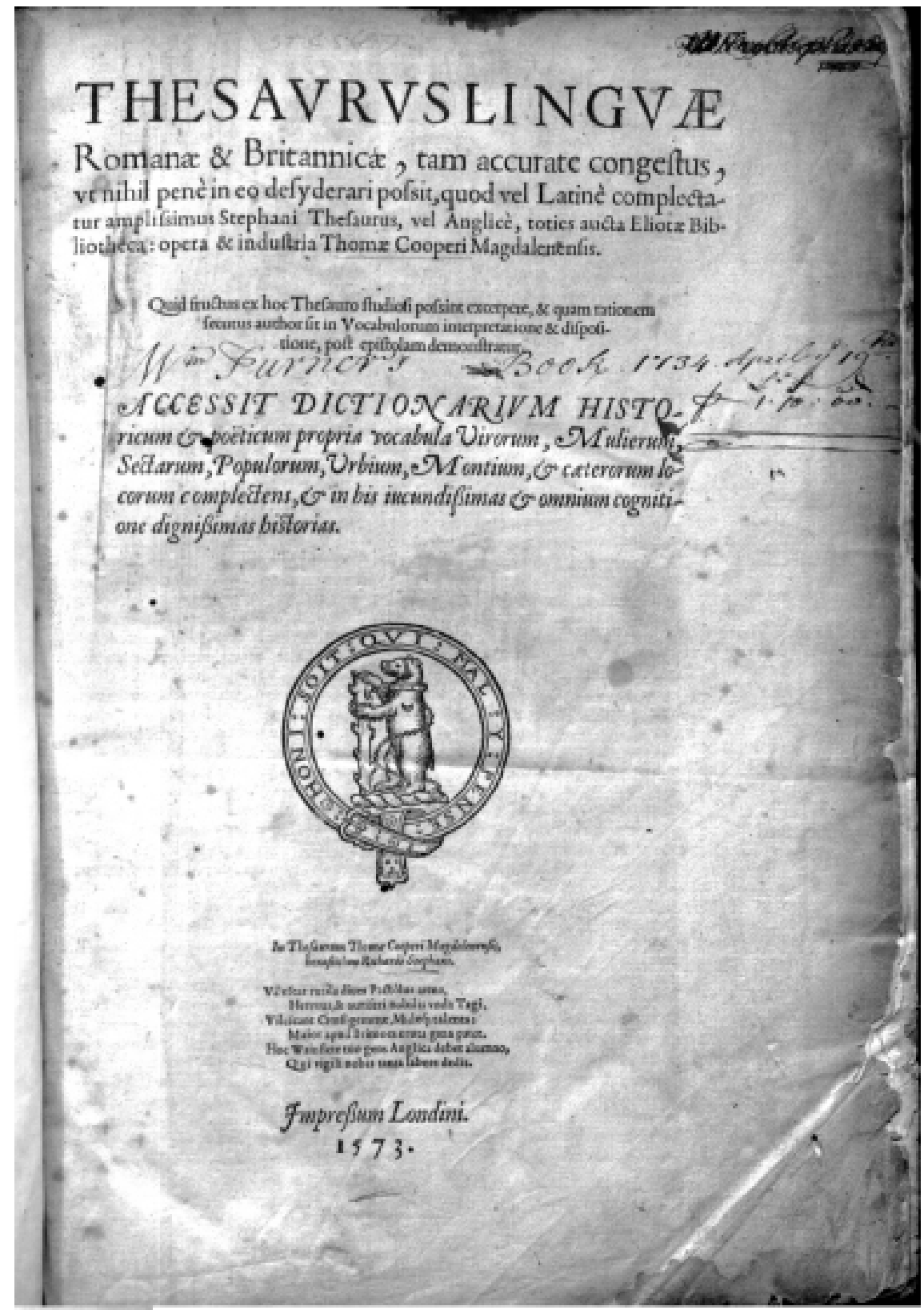

Figure 2.I Cooper, Thomas. Thesaurus linguae Romanae et Britannicae. . . I573 (from Edward J. Bloustein Dictionary Collection, Special Collections and University Archives 
effects on literature, social and political history, law, and other linguistically sensitive fields.

The earliest works of recognizable English lexicography were really bilingual word lists, and works such as Cooper's Thesaurus linguae Romanae et Britannicae fall into this category. Cooper's work, of which the Bloustein collection has a first edition dated 1573, expanded an earlier Latin-English glossary by Sir Thomas Elyot, and it influenced the early monolingual dictionaries of the next century. It was almost lost to the world before it ever saw print, however. Tradition has it that Cooper's wife, upset that his work was keeping him up so late, snatched the half-finished manuscript from his study and burned it. Not one to be easily discouraged, Cooper reputedly began the work again from scratch, this time, no doubt, keeping a closer watch on it. John Minsheu's The Guide into tongues ... , first published in 1617 and represented in the Bloustein collection by editions from I625 and 1627, was similar in approach but considerably more ambitious: a multilingual dictionary that used illustrative quotations from authors in ways that may be said to have anticipated Samuel Johnson. It included sets of equivalent terms from as many as eight different languages.

The earliest monolingual dictionary in the collection is a 1930 facsimile of Henry Cockeram's English dictionarie of 1623. Like other monolingual English dictionaries of this period, it is essentially a "hard word" glossary. At the time, it was not considered necessary to define the common terms and function words that make up so much of the bulk of modern dictionaries, ${ }^{2}$ and lexicographers like Cockeram concentrated on giving everyday equivalents for Latinate words, many of them "inkhorn terms" that were rarely if ever actually used. Cockeram indexed his word lists in two separate sections, a bit like a bilingual dictionary, with a difficult-to-common list followed by a corresponding common-to-difficult list. He also included a novel third section of encyclopedic material.

Much of the history of lexicography was driven by what one might call extended publishing rivalries, the most famous of which were those of Bailey's and Johnson's, and later Webster's and Worcester's, dictionaries. The Bloustein collection documents these rivalries extensively, beginning with the more obscure seventeenth-century rivalry of Thomas Blount and Edward Phillips. Blount first published his Glossographia, or A dictionary interpreting all such bard words . . . as are now used in our refined English tongue . . . in I656. Phillips, a nephew of the poet John Milton, followed two years later with The Moderne 


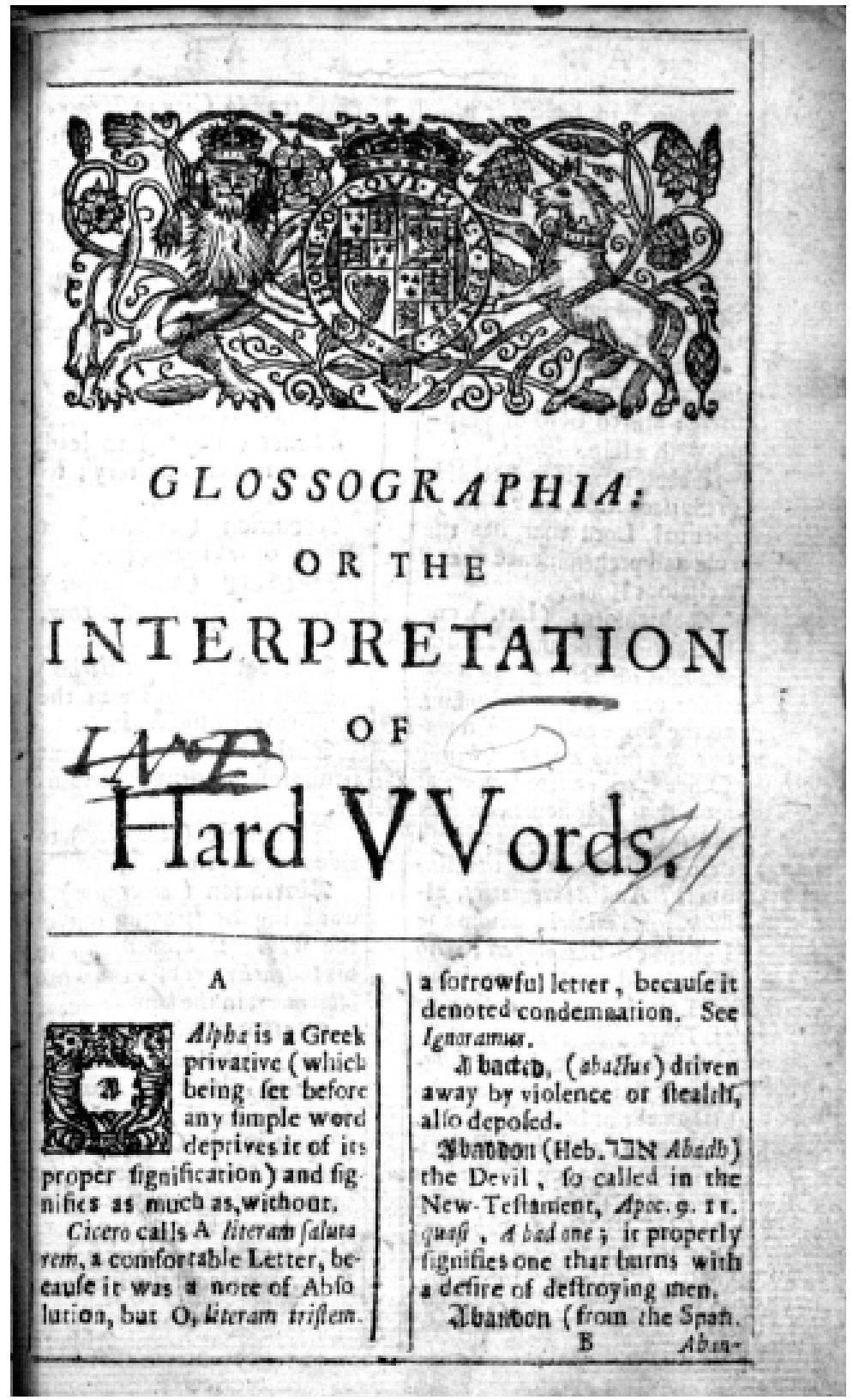

Figure 2.2 Blount, T[homas]. Glossographia, or A Dictionary interpreting the hard words. . . . 5th ed. I68I (from Edward J. Bloustein Dictionary Collection, Special Collections and University Archives) 
world of words, or, A Universall English dictionary, collected from the best authors (later titled The New world of English words....). Blount's work was remarkable for incorporating scientific words and-for the first time-rudimentary etymologies. It also included citations of reading sources for certain terms, ${ }^{3}$ as well as woodcut illustrations. Phillips's work, which included encyclopedic material from other sources, borrowed heavily from Blount for his lexicographic material without acknowledgment, which so angered the latter that he published a work attacking Phillips titled $A$ World of Errors Discovered in the New World of Words. Both works were frequently reprinted, and the Bloustein collection contains four editions of Blount ranging in date from I656 to I68I and five editions of Phillips ranging in date from I658 to I720. It also includes three editions of a work influenced by Phillips, Elisha Coles's An English dictionary . . . first published in 1676 and represented by editions from I692, I7 I7, and I732. Coles was one of the first English lexicographers to include slang and dialect terms in a general dictionary. Phillips also influenced the work of John Kersey, considered by some scholars to be the "first professional lexicographer," ${ }^{4}$ whose book A New English dictionary ... appeared in 1702. The Bloustein collection contains a first edition and a facsimile of this work, as well as two editions of Kersey's later work, Dictionarium Anglo-Britannicum, or, A General English dictionary. ... Kersey was the first lexicographer to concentrate on an expanded lexicon of common English words, including words with multiple senses, to the exclusion of obsolete or artificial Latinate vocabulary. In addition to writing his own dictionaries, Kersey revised the later editions of Phillips, one of which, the 1720 edition, is represented in the Bloustein collection.

The great rivalry of the eighteenth century was that between Nathaniel Bailey and Samuel Johnson. Bailey's An Universal etymological English dictionary.. ., first published in I72I, was revised and reprinted throughout the century. Greatly expanding Kersey's word list, Bailey was responsible for several innovations that characterize modern dictionaries, including detailed etymologies, stress marks hinting at pronunciation, and even usage information. Later editions, revised by Joseph Nichol Scott to compete with Johnson's dictionary, added sets of beautiful pictorial illustrations, which Johnson, beginning a tradition adhered to by most British dictionaries to this day, eschewed. Bailey's dictionary marked the last appearance of certain taboo words, albeit with definitions discreetly phrased in Latin, in a general English dictionary. 


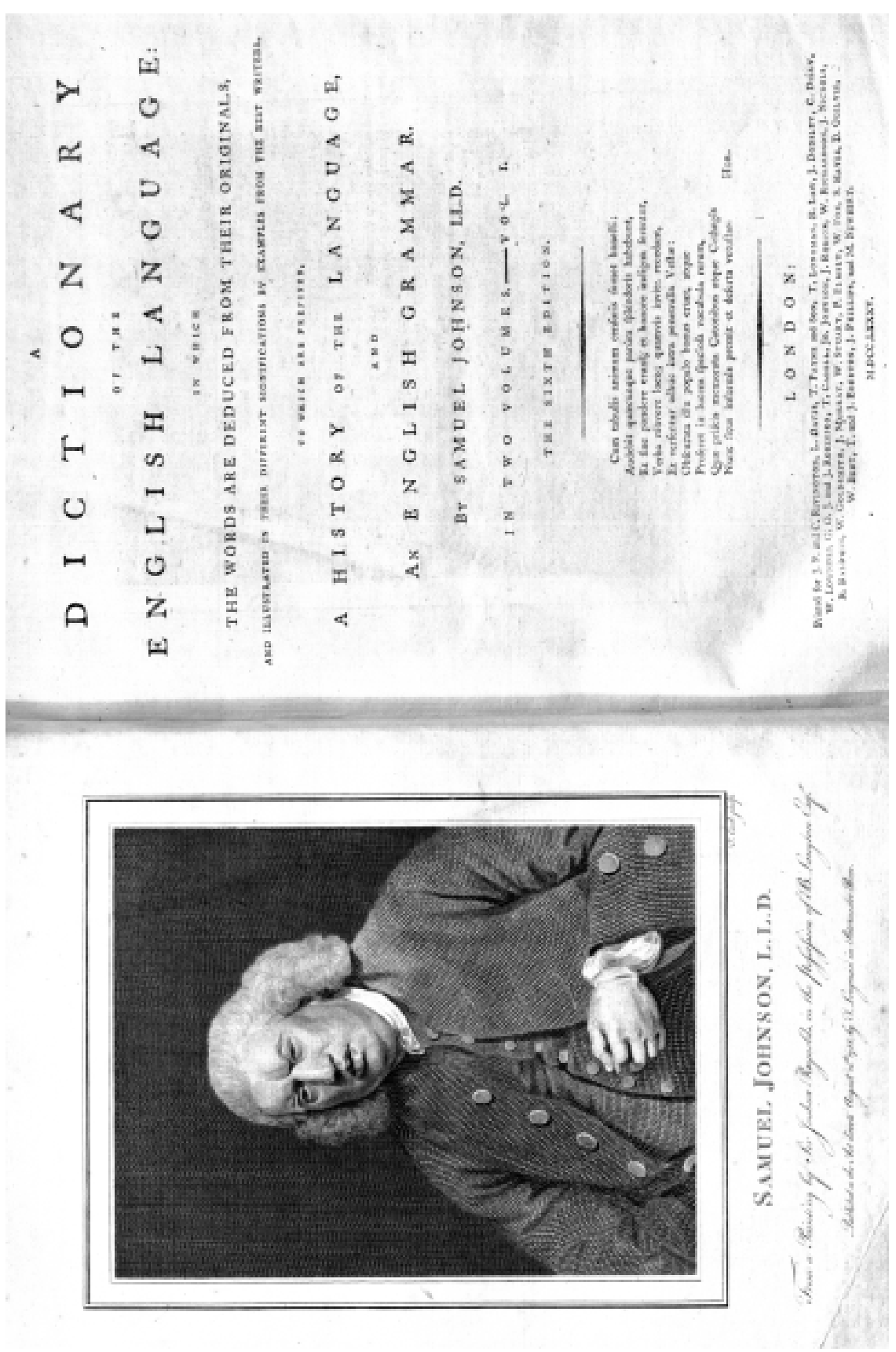

Figure 2.3 Johnson, Samuel. A Dictionary of the English language. . . . 2 vols. 6th ed. 1785 (from Edward J. Bloustein Dictionary Collection, Special Collections and University Archives) 


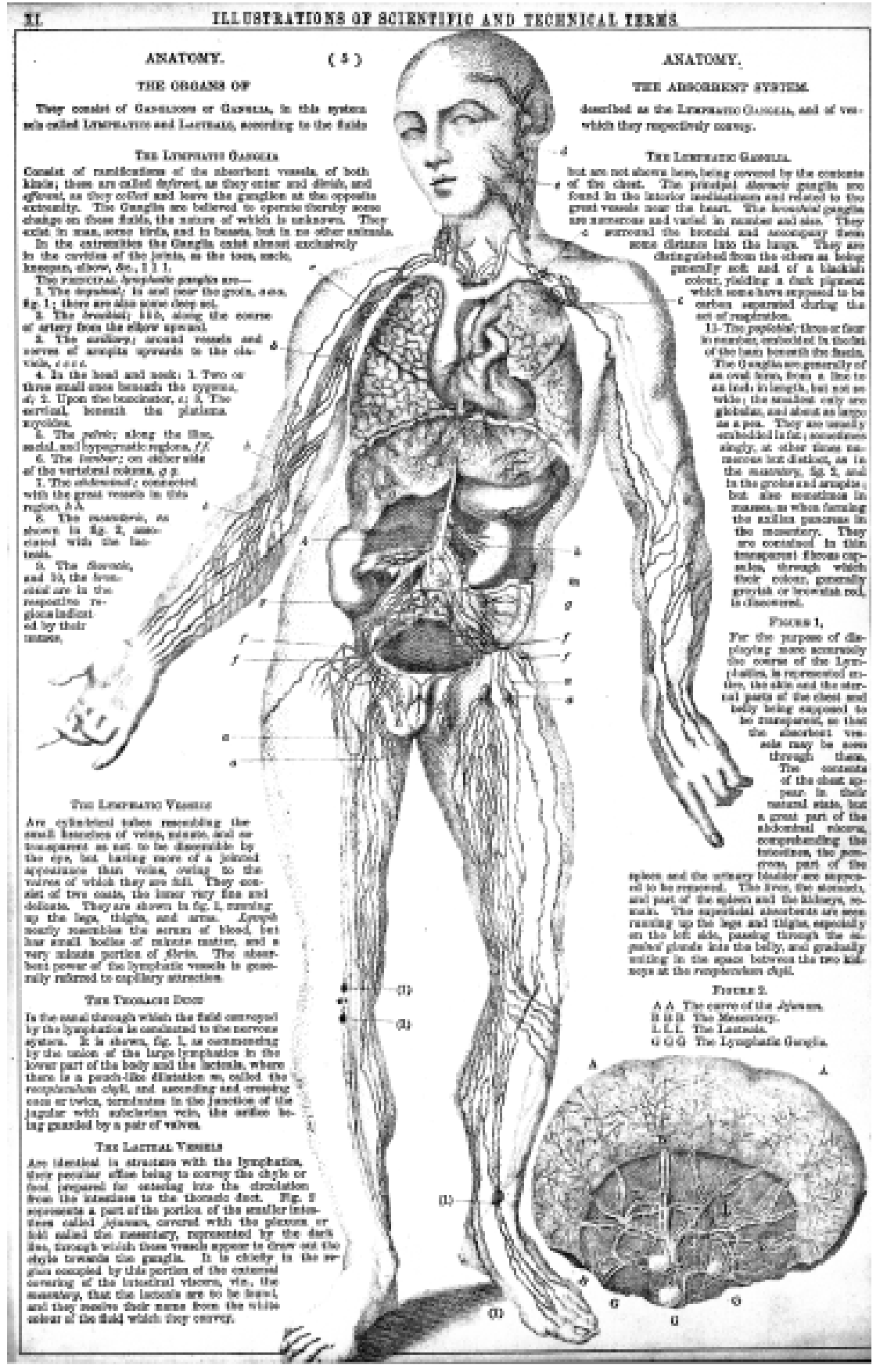

Figure 2.4 Boag, John. The imperial lexicon of the English language. . . . 2 vols. [ca. I850?] (from Edward J. Bloustein Dictionary Collection, Special Collections and University Archives) 
Johnson's A Dictionary of the English language ... is considered by many to be the first modern English dictionary. It was certainly the first English dictionary to be produced with something approaching scientific principles; indeed, until quite recently when they began to be superseded by the use of computers and electronic resources, Johnson's working methods, such as the hand carding of individual citations or word slips, were still being used by most lexicographers, including the editors of Webster's and the OED. Inspired by the success of such foreign projects as the Dictionnaire de l'Académie française, Johnson began by publishing an ambitious Plan of a Dictionary of the English Language in I747. Working with a handful of assistants in his now famous "garret," Johnson completed the dictionary in the remarkably short span of nine years, though admittedly not in full accordance with the plan. Upon its publication in I755, Johnson's A Dictionary of the English language ... immediately became the standard against which all other English dictionaries were to be judged, and in comparison with which almost all would be found wanting for many years. Johnson broke new ground with his etymologies, his deep, polysemous definitions, and his extensive use of illustrative citations, which had a great influence on later lexicographers including the editors of the OED.

This did not keep others from trying, however, as the publication history of Bailey's suggests. Scholars wishing to trace the history of the BaileyJohnson rivalry will be richly rewarded by the Bloustein collection, which contains no less than eight editions of Bailey and Bailey-Scott ranging from I728 to 1782 and eleven editions of Johnson, including the later revisions by H.J. Todd, ranging from the first edition of I755 to I882. Among the Johnson editions is an interesting Philadelphia publication from I8I8 spruced up, as it were, with material from John Walker's Principles of English pronunciation. Walker's own "pronouncing dictionaries," which were enormously popular in the first half of the nineteenth century, are represented in the collection by six editions dating from 1775 to I85I. Like Noah Webster after him, Walker conceived of lexicography as a teaching function, and so he used his dictionaries as vehicles for a prescriptivist crusade against what he considered to be "incorrect" pronunciations. Walker was not the first lexicographer to employ a regular and consistent system of phonetic respelling. That honor belongs to his early descriptivist rival, Thomas Sheridan, whose A Complete dictionary of the English language, both with regard to sound and meaning is also represented in the Bloustein collection, by three editions from 1790 and I8II. Walker 
refined Sheridan's phonetic system, however, in ways that still seem remarkably modern. Walker's influence was especially strong in the United States. Sidney Landau claims that many current American pronunciations, such as /med'de$\mathrm{cin} /$ for medicine as opposed to the English / med'sin/, can be traced directly to Walker's conservative strictures against dropping syllables in the pronunciation of words. ${ }^{5}$

The most famous lexicographic rivalry of them all is no doubt that of Noah Webster and Joseph Worcester for the hearts and minds of nineteenthcentury American readers. Webster worked as a schoolteacher, a lawyer, and a journalist before publishing his first real dictionary, ${ }^{6}[\mathrm{~A}]$ Compendious dictionary of the English language ...., in I806. This early work, which was based on John Entick's Spelling dictionary... (first edition, 1764; the Bloustein collection has two later editions of Entick's new spelling dictionary ... , from I79I and I804), was little more than a promise of things to come. It contained 40,000 entries with relatively short definitions. Its chief distinctions were the inclusion of certain American terms and the splitting out, for the first time, of the letters I-J and U-V, which had traditionally been used interchangeably and had hitherto been alphabetized together in dictionaries. It did not even include etymologies. ${ }^{7}$ The next year Webster began his much more ambitious project, An American dictionary of the English language . . . which was not published until I828, when he was already seventy years old. Comprising two folio volumes, the 1828 edition contained 70,000 entries, compared with 55,000 in the most recent Johnson-Todd edition, and tens of thousands of previously undefined senses. It was not a great financial success, but it sold more copies in England than in the United States, in spite of - or perhaps scandalously because of - its decided preference for American usages and "unconventional" American spellings. Although indebted to Johnson for many of its literary words and definitions, it established what could almost be considered an American lexicographic tradition by its prominent inclusion of technical and scientific vocabulary. Webster himself completed a second edition (I84I) before his death in I843, after which the rights to the work were acquired by the G. \& C. Merriam Company (now known as Merriam-Webster), which has continued the publication of "Webster's dictionaries" to the present day.

The first Merriam revisions of Webster's dictionary (I847-I859) were edited by Webster's son-in-law, Chauncey A. Goodrich, during the height of what came to be known as "the dictionary war." Joseph Worcester, another 
former schoolteacher who had created an abridged version of Webster's dictionary for Goodrich in I829, first published his own dictionary, titled $A$ Comprehensive pronouncing and explanatory dictionary of the English language, with pronouncing vocabularies of classical and scripture proper names, in I830. Webster, who had learned from his experience with pirated editions of the early spelling book the value of jealously guarding his intellectual property, was not long in accusing Worcester of plagiarism, which precipitated the protracted "war" between the dictionaries. Worcester had actually begun his own dictionary before his work for Webster, and it was really no more indebted to Webster than any lexicographer is almost bound to be to a near predecessor. In general, Worcester's dictionary was more cautious than Webster's in its approach to etymology, pronunciation, usage, and orthography, and it became the favorite of more conservative readers. Worcester beat Chauncey Goodrich to market with a major revision in I846, and ended by answering the illustrated I859 Webster's with his own finest work in A Dictionary of the English language, published in 1860. It contained more than 100,000 entries and about 1,000 illustrations. Worcester's dictionaries included a number of innovations that were to be widely copied, such as the inclusion of synonym discussions in a work of general lexicography. Although he may be said to have more than held his own in the dictionary battles, Worcester lost the war itself when he died in I865 without having answered the famous I864 "unabridged" edition of Webster's, edited by Noah Porter with help from such luminaries as the etymologist Karl Mahn and the linguist William Dwight Whitney. ${ }^{8}$ The Worcester dictionary continued to be issued as late as the minor revision of I886, but it was never seriously revised after his death and went out of print completely by the end of the century. The I864 edition of Webster's, on the other hand, represented a "new beginning" and may be regarded as the true ancestor of the modern line of Merriam-Webster dictionaries that began with the International Dictionary of $\mathbf{l} 890$.

The Bloustein collection contains an almost complete collection of the Webster and Worcester dictionaries, including first editions of the I806 and I828 Webster's and the I830 Worcester's. All told, there are eighteen separate editions of Webster's dictionaries ranging from I806 to I96I and four editions of Worcester's dictionaries ranging from I830 to I88I, affording scholars an opportunity to trace in detail the Webster-Worcester rivalry as well as the continued history of Webster's dictionaries, including the scandals that attended Philip Gove's I96I revision of William Allan 


\title{
A NEW \\ ENGLISH DICTIONARY \\ ON HISTORICAL PRINCIPLES;
}

\author{
FOUNDED MAINLY ON THE MATERIALS COLLECTED BY \\ Ebt fabilological society. \\ votTE is \\ JAMES A. H. MURRAY,

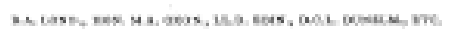

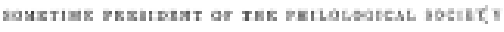

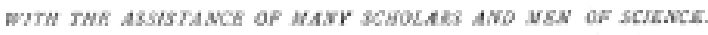

VOLOME I. $\triangle \triangle A N D B$.

PARP I A.

By J. A. H. MURRAY.

OXFORD :

AT THE CLARENDON PRESS.

1888.

[As ryste numod]

Figure 2.5 The Oxford English Dictionary. A New English dictionary on historical principles. ... I0 vols. I888-1928 (from Edward J. Bloustein Dictionary Collection, Special Collections and University Archives) 
Neilson's beloved Second New International Dictionary (1934).9 One regrets only the absence of the original 1890 edition of the New International, which is represented by an edition from I905, and the I860 Worcester's, which is represented by editions from 1874 and I88I.

While the dictionary war raged in America, lexicography in Britain, though still dominated by Johnson, was hardly standing still. In Scotland, John Jamieson edited a series of dictionaries of Scots in the early nineteenth century that are still influential. In I850, another Scot, John Ogilvie, published the first edition of The imperial dictionary, English, technological, and scientific, adapted to the present state of literature, science, and art, on the basis of Webster's English dictionary...., which is represented in the Bloustein collection by editions from I856, I859, and I863. As the title acknowledged, Ogilvie based his dictionary on the I847 edition of Webster's, but The imperial dictionary was no mere imitation, and indeed it broke new ground with its inclusion of a large and beautiful series of in-line woodcut illustrations well before Webster's or Worcester's had anything like them. ${ }^{10}$ A version of The imperial dictionary (the 1882 revision by Charles Annandale) was licensed from Blackie \& Sons by the Century Company of New York and served as the basis for the illustrious Century Dictionary edited by Whitney and Benjamin E. Smith-completing the circuit, as it were, of transatlantic borrowing and influence.

Taking another direction altogether, Charles Richardson, an English follower of John Horne Tooke, who believed, contrary to Johnson, that each word had only one meaning, sought to prove his theories in A New dictionary of the English language (I836-I837). This novel work, of which the Bloustein collection has four editions ranging from I836 to I844, was chiefly remarkable for its hitherto unprecedented collection of illustrative quotations, far surpassing Johnson's in number and dating from as early as the fourteenth century. Richardson felt that the quotations spoke for themselves, giving the history of each word and thus expanding the meaning of his otherwise meager definitions. Indeed, most of the bulk of what became a four-volume work is taken up by the systematic presentation of these quotations. Although most scholars would agree that he did not prove his or Tooke's theories, his approach had a considerable influence on the OED.

The history of the OED has been fully discussed elsewhere and needs only a brief précis in this space. ${ }^{11}$ The idea for $A$ New English dictionary on bistorical principles, founded mainly on the materials collected by The Philological Society, as it was first called, originated with a series of papers given at the Philological 
Society of London in 1857 by Richard Trench, then the dean of Westminster. Trench had been asked to review previous dictionaries, identify their weaknesses, and make recommendations on whether it would be better to adapt an older dictionary, such as Johnson's or Richardson's, or to edit a new dictionary from scratch. His paper, "On some Deficiencies in our English Dictionaries," served as the basis for a proposal for a completely new dictionary, which was adopted by the Philological Society in I859. Herbert Coleridge, a grandson of the poet, was chosen as the first editor, though Frederick Furnivall, the founder of the Early English Text Society, succeeded him after his early death in I86I. ${ }^{12}$ Furnivall oversaw the initial reading and "sub-editing" for the dictionary, but real editing did not begin until James A. H. Murray, a Scottish schoolteacher, took over as editor in 1879 at the invitation of the Philological Society. Furnivall had been more enthusiastic than methodical, and it was left to Murray to restart the project in a practical way.

Murray organized a large reading program composed of paid readers and volunteers who read through all of English literature from Anglo-Saxon times to the present and garnered millions of four-by-six word slips to present a historical record of actual usage for every sense of every word not already obsolete by II50. In certain respects, combining Johnson's polysemous approach with Richardson's massing of citation evidence, Murray selected and ordered the quotations, along with the more usual lexicographic tasks of determining pronunciations, writing etymologies, and defining discrete senses for each word. Murray was able to produce the first of many serially published "fascicles" representing the letters A and B by I884, but it quickly became apparent that the scope of the work was too much for one man. Oxford University Press had become involved as a co-sponsor of the work with the Philological Society, and it soon took over the major role of publication. Henry Bradley was brought in as a second editor in I888 to work separately on his own ranges of the alphabet. In I90I, William Craigie, another Scot, became the third editor, and Charles T. Onions ${ }^{13}$ came on in I9I4 as the fourth and final editor of the original team. Murray himself remained the heart and soul of the project, and before he died in I9I5 he had been personally responsible for more than half of the entries in the dictionary, which was finally completed in twelve volumes in 1928.

By the time of its publication, the two surviving editors, Craigie and Onions, were already planning a one-volume supplement of material picked 

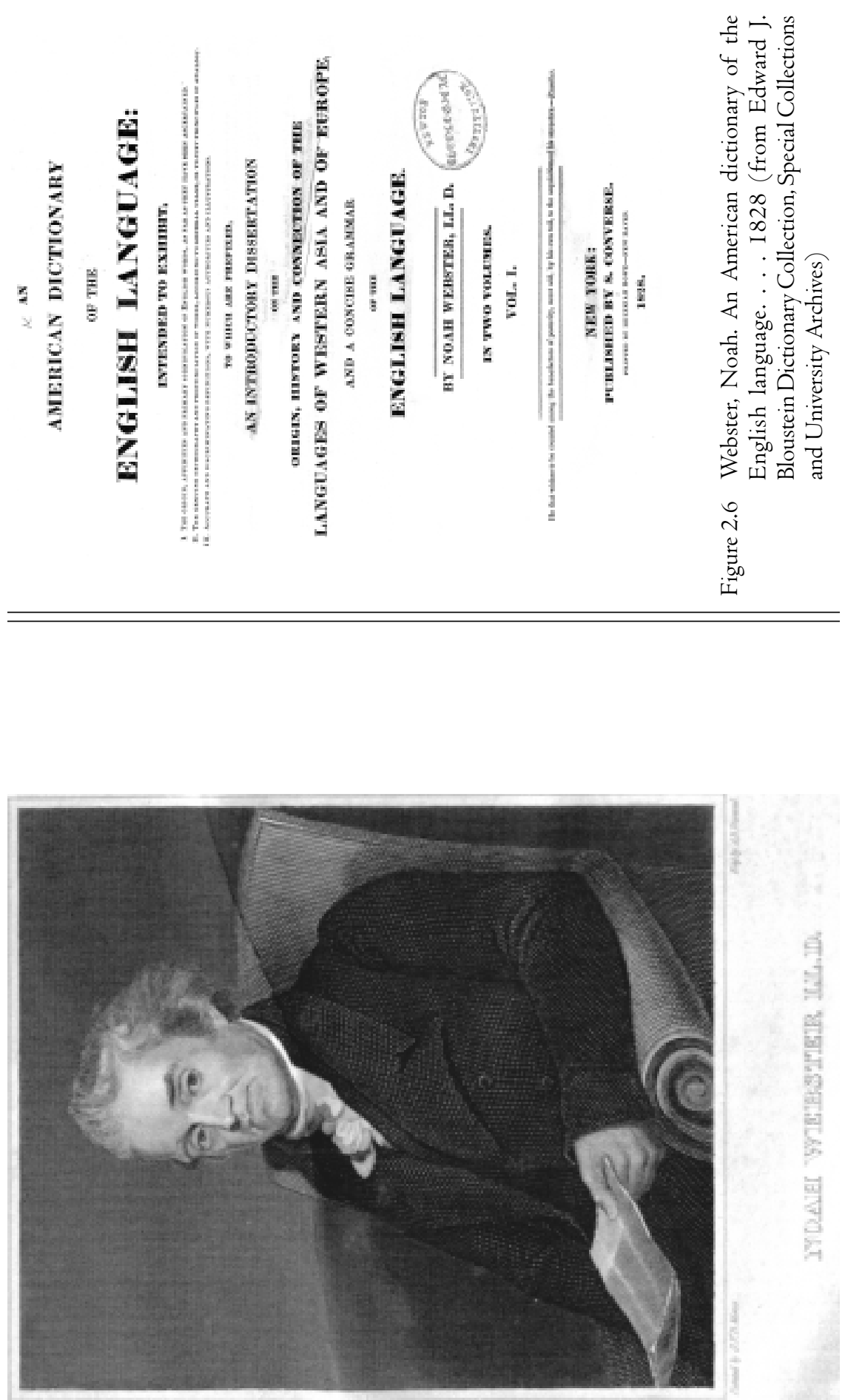
up too late for inclusion in the earlier ranges of the alphabet. This first Supplement to what had already become known as the Oxford English Dictionary was published in 1933, after which the remaining materials were disbursed according to a plan that Craigie articulated in a paper given in 1919. The word slips for quotations used in the OED itself, representing about a quarter of the total collected, were deposited at the Bodleian Library. The remaining slips were partitioned and sent to various locations as a means of jumpstarting a series of specialized "historical dictionaries" modeled on the OED. ${ }^{14}$ The OED's editorial office was effectively disbanded until 1957, when Robert Burchfield, a Rhodes scholar from New Zealand who had studied with Onions, was chosen to edit what became the four-volume Supplement (I972I985) updating the dictionary with recent words and scientific vocabulary that had been relatively ignored in the original OED. Burchfield, who organized his own reading program and trained an entirely new staff, many of whom are still involved with editing the OED, may be credited with giving new life to the work-in its present form, twenty volumes defining more than 600,000 words and phrases - that some scholars consider the greatest of all dictionaries.

The Bloustein collection includes a complete first edition of the OED from 1928, as well as a set of rare early fascicles, "Vol. III, Part I. E-Every ...., published in I89I and representing the first range completed by Henry Bradley. One only wishes there were more fascicles, which provide scholars with interesting "windows" into the composition of the dictionary at various stages, as well as the 1933 and 1972-I985 Supplements.

This brings us to consideration of a few areas where the collection's coverage might be enhanced. There are a few important dictionaries from various periods that are notably absent from the collection. Among the missing early works are two significant English dictionaries that appeared before Cockeram's: Robert Cawdrey's Table Alpbabeticall (I604), which is usually credited as the first English dictionary, and John Bullokar's An English Expositor (I6I6), which heavily influenced Cockeram and, in subsequent editions - it was reprinted as late as I73 I-competed with the Cockeram dictionary almost in the manner of the later Bailey-Johnson and Webster-Worcester rivalries.

Among the important nineteenth-century works that are needed to perfect the otherwise outstanding Bloustein collection are John Jamieson's Etymological Dictionary of the Scottish Language ( I808, I825), Edward H. Knight's American Mechanical Dictionary (I872-I88I), William Dwight Whitney's 
magisterial Century Dictionary and Cyclopedia (I889-I9II), and the Funk E Wagnalls Standard Dictionary of the English Language (I893; New Standard Dictionary, I9I3). These are fairly serious omissions. The Jamieson dictionary, though especially concerned with Scots, was among the finest lexicographical works of the early nineteenth century, and it has extended its influence into the twentieth century through such later works as the Dictionary of the Older Scottish Tongue and the Scottish National Dictionary. Knight's American Mechanical Dictionary was the authoritative technological dictionary of its day, the dictionary for such people as Henry Ford and the Wright brothers, and a major source of technical information for other, general reference works, such as The Century Dictionary, Webster's International and New International dictionaries, and the OED. The Century Dictionary, which rivaled the $O E D$ in size and scope and surpassed it in certain respects, is still considered by many scholars to be the greatest American dictionary ever produced. The Funk \& Wagnalls Standard Dictionary, a serious competitor of the earlier Webster's International and New International dictionaries, was the first dictionary to order its senses by frequency of use rather than historical appearance, a practice now quite common in general synchronic dictionaries, and the first dictionary to move etymologies to the end of its entries, another practice carried on by such modern works as The Random House Dictionary.

Among twentieth-century dictionaries, in addition to the $O E D$ supplements (the 1933 Supplement edited by C.T. Onions and the four volume 1972-1985 Supplement edited by Robert Burchfield), the major dictionaries on historical principles are conspicuously absent, as are several important slang dictionaries, particularly those edited by John Stephen Farmer, Eric Partridge, and Harold Wentworth.

It should be pointed out that the regular collection of the Alexander Library makes up for many of these omissions, and Bloustein may simply have been avoiding duplicating works that he knew to be in the regular collection of the library. The Alexander Library contains a 1970 facsimile of Cawdrey and a 1967 facsimile of Bullokar. There is also an I8I8 edition of Jamieson's own abridgment of his dictionary, apparently aimed at an English market eager for some means of deciphering the language of Walter Scott's novels. There are at least two copies of The Century Dictionary (a tenvolume edition from 1900 and a full twelve-volume set from I9II) and several editions, including a first edition, of Funk \& Wagnalls. The OED supplements are also to be found in the regular Alexander collection. In 
addition, the Alexander Library owns several of the great regional dictionaries on historical principles, such as the Dictionary of American English, the Dictionary of Americanisms, the Dictionary of American Regional English, and the Dictionary of the Older Scots Tongue, though not the Middle English Dictionary ${ }^{15}$ or the Scottish National Dictionary. The Alexander Library also has a good selection of slang dictionaries by Farmer, Partridge, and Wentworth.

So far, I have considered mainly the Bloustein collection's general dictionaries. There are also many specialized works in the collection, such as synonym dictionaries, biographical dictionaries, and dictionaries of slang, technical terminology, and proverbs. The collection of synonym dictionaries is especially noteworthy, with no less than twenty-seven editions of eleven separate works. The earliest of these is John Trusler's two-volume The Difference between words esteemed synonymous in the English language ... . , with editions from I776 and I804. The most recent is Joseph Devlin's A Dictionary of synonyms and antonyms and 5,000 words most often mispronounced, published in 1942. Some historically important synonym dictionaries are represented in the Bloustein collection by nearly complete publishing ranges. There are thirteen editions (I8I6-I9I7) of the Englishman George Crabb's English synonymes explained, in alphabetical order ..., and all three editions (I896-19I4) of a major American work, James Fernald's ... English synonyms and antonyms, with notes on the correct use of prepositions.

Slang dictionaries are not covered as completely as synonym dictionaries in the collection, though, as noted above, this deficiency is made up for to some extent by the regular collection of the library. There are three editions (I785-I796) of Francis Grose's early slang dictionary, A Classical dictionary of the vulgar tongue, as well as two editions (I8II, 1984) of a later revision entitled ... A Dictionary of buckish slang, university wit, and pickpocket eloquence, among other works.

The so-called biographical dictionaries are perhaps more properly denoted as specialized encyclopedias, since they do not treat the lexicon as their primary subject, but the name "dictionary" has stuck with them through the years. The most notable examples, Leslie Stephens's Dictionary of National Biograpby and the American National Biography, are not here, though they are in the library's regular collection. The Bloustein collection does have several notable precursors, however, such as William Allen's An American biographical and bistorical dictionary, containing an account of the lives, characters, and writings of the most eminent persons in North America from its first discovery to the present time, and a 
summary of the bistory of the several colonies and of the United States, published in I809; Charles Anthon's A Classical dictionary, containing an account of the principal proper names mentioned in ancient authors, and intended to elucidate all the important points connected with the geography, bistory, biography, mythology, and fine arts of the Greeks and Romans, together with an account of coins, weights, and measures, with tabular values of the same, published in I84I; and R. A. Davenport's A Dictionary of biography, comprising the most eminent characters of all ages, nations, and professions, represented by an illustrated American edition from I842.

Specialized lexicographic works of particular interest are a I768 fourth edition of John Ray's A Compleat collection of English proverbs ... to which is added. .. A Collection of English words not generally used . . . first published in 1670; a I 966 facsimile of John Harris's two-volume Lexicon Technicum, or An Universal English dictionary of arts and sciences, the "Knight's Mechanical Dictionary" of I702; and John Pickering's early "dictionary of Americanisms," A Vocabulary, or collection of words and phrases which bave been supposed to be peculiar to the United States of America, to which is prefixed an essay on the present state of the English language in the United States...., published in I8I6, more than a century before William Craigie and Mitford Mathews began their multivolume treatments of the subject.

As I mentioned at the beginning of this essay, it is quite rare for any individual to gather together a collection of dictionaries as comprehensive as that of Edward Bloustein. It is even rare to find such a collection in university libraries. Apart from the incomparable Cordell Collection at Indiana State University, which was begun with a similar gift in 1969 and has been aggressively augmented ever since, there are very few important collections of general dictionaries in the United States. The Cincinnati Public Library has the Louis E. Kahn Collection of Dictionaries, and an important American specialized collection is the Law Dictionary Collection at the University of Texas School of Law. Abroad, the University of Glasgow has a major collection of general dictionaries dating from the fifteenth century. The addition of the Bloustein collection provides the Rutgers University Libraries with the basis of what could easily become a major center of lexicographical research. Once known, the Bloustein collection will without a doubt engage the attentions of scholars and donors not just within the Rutgers community but far and wide beyond it. 


\section{Notes}

I. "The art or practice," in Samuel Johnson's phrase, "of writing dictionaries."

2. The $O E D$ entry for set (v.I), for instance, takes up fifty three-column pages.

3. Alan Walker Read claims that Blount was the first lexicographer to use "authority" in this sense, for which Phillips opportunistically attacked him. See "The History of Lexicography" in Lexicography: An Emerging International Profession, ed. Robert Ilson (London: Manchester University Press, I985), 3 I.

4. Alan Walker Read quoted in Sidney I. Landau, Dictionaries: The Art and Craft of Lexicograpby (New York: Charles Scribner's Sons, I984), 44.

5. Landau, Dictionaries, 58.

6. His enormously successful American Spelling Book, which anticipated his future endeavors, was published as early as 1783 .

7. Etymologies would remain a problem for Webster and a weak point in his later dictionary through several editions. Although he was working at the time when Franz Bopp, Rasmus Kristian Rask, and the Grimm brothers were revolutionizing philology, he never considered the new theories seriously, and thus rendered his own etymologies almost immediately obsolescent. The Webster etymologies were not revised on scientific principles until Karl Mahn overhauled them for the I864 edition issued by the G. \&. C. Merriam Company.

8. Whitney was later to gain lexicographic renown as the chief editor of The Century Dictionary (1889). The I864 edition of Webster's was also a primary resource for James Murray, the editor of the OED, who was under promise to the delegates of Oxford University Press not to allow any entries in his dictionary to exceed the length of seven times the space accorded the corresponding entry in the I864 Webster's. It was a promise he could not always keep.

9. For the best discussion of this lexicographic controversy, see Herbert Morton, The Story of Webster's Third: Philip Gove's Controversial Dictionary and Its Critics (Cambridge, England, and New York: Cambridge University Press, 1994).

I0. The imperial dictionary remains an oddity among British dictionaries because of this. Most of them continue to follow Johnson in excluding pictorial illustrations. 
II. The best book on the OED is still Caught in the Web of Words: James A. H. Murray and the Oxford English Dictionary, written by Murray's granddaughter, Elizabeth K.M. Murray, and published by Yale University Press in 1977 with a preface by the late Robert Burchfield.

12. The dedicated but ill-fated Coleridge reportedly died in a bed strewn with word slips intended for the new dictionary. He is represented in the Bloustein collection by a minor work, A Dictionary of the first, or oldest words in the English language.... , published in I863.

13. Tradition has it that he preferred his name to be pronounced /o-nirns/.

I4. Craigie, who joined the faculty of the University of Chicago in I925, was personally involved in editing two of these works, the Dictionary of American English (1938-1944) and the Dictionary of the Older Scottish Tongue (1937-2002).

I5. The Rutgers University Libraries do own several copies of the less ambitious $A$ Middle English Dictionary edited in the nineteenth century by Francis Stratmann. 